\title{
Effect of Exposure to Bisphenol A and 17ß-estradiol on the Sex Differentiation in Zebrafish (Danio rerio)
}

\author{
J. DRASTICHOVÁ ${ }^{1}$, Z. SVOBODOVÁ ${ }^{1,2}$, M. GROENLAND ${ }^{3}$, R. DOBŠÍKOVÁ ${ }^{1}$, \\ V. ŽLÁBEK ${ }^{2}$, D. WEISSOVÁ ${ }^{4}$, M. SZOTKOWSKÁ \\ ${ }^{1}$ University of Veterinary and Pharmaceutical Sciences Brno, Czech Republic \\ ${ }^{2}$ University of South Bohemia České Budějovice, Research Institute of Fish Culture \\ and Hydrobiology, Vodňany, Czech Republic \\ ${ }^{3}$ Utrecht University, The Netherlands \\ ${ }^{4}$ Masaryk University, Faculty of Science, Brno, Czech Republic
}

Received September 1, 2004

Accepted March 3, 2005

\begin{abstract}
Drastichová J., Z.Svobodová, M.Groenland, R. Dobšíková, V. Žlábek, D. Weis sová, M. Szotkowská: Effect of Exposure to Bisphenol A and 17ß-estradiol on the Sex Differentiation in Zebrafish (Danio rerio). Acta Vet. Brno 74, 2005: 287-291.

The effects of bisphenol A and 17ß-estradiol on sex differentiation were investigated in the zebrafish, Danio rerio. The 20-day-old fry with undifferentiated gonads were fed with food containing bisphenol A at the dose of 500,1000, $2000 \mathrm{mg} \cdot \mathrm{kg}^{-1}$ and $17 ß$-estradiol at the dose of 20 $\mathrm{mg} \cdot \mathrm{kg}^{-1}$ diet for 45 days. Sex ratio and gonadal development after the chemical treatment were determined by histological examination of gonads. In the control group, the sex ratio of fry was 1:1 (female:male), i.e. $50 \%$ of females and $50 \%$ of males appeared. The sex of fry fed with $17 ß$-estradiol at the dose of $20 \mathrm{mg} \cdot \mathrm{kg}^{-1}$ diet was all females. Feminization of the fry was induced by exogenic 17ß-estradiol. The sex of fry fed with bisphenol A at the dose of 500, 1000, $2000 \mathrm{mg} \cdot \mathrm{kg}^{-1}$ diet was 1.4:1 $(p=0.31), 3.8: 1(p=0.01)$ and 11.5:1 $(p<0.01)$. Bisphenol A induced feminization of the fry at the two highest doses tested.
\end{abstract}

Endocrine disrupters, $17 \beta$-estradiol, fish, sex ratio

Assessment of fish reproductive performance is increasingly used to evaluate the impact of environmental disturbances (Bjerselius et al. 2001). Concern for the successful development and reproduction of fish population has been addressed to endocrine disrupting chemicals (EDCs). These are, broadly defined, natural and man-made agents present in the environment that interfere in some ways with normal endocrine function (Arcand-Hoy and Bens on 1998). The ability to interfere with the endocrine system is found in several classes of environmental chemicals such as organochlorine pesticides and its metabolites, polychlorinated biphenyls, dioxin-like chemicals, bisphenolic compounds, alkylphenolic chemicals, some fungicides, phtalate plasticisers and antifouling paints (Tyler et al. 1998).

Endocrine-disrupting compounds have the potential to perturb sensitive hormone pathways that regulate reproductive functions. Developmental and reproductive toxicity may occur during larval development or the juvenile or adult stage. Exposure at an early life stage may lead to alterations in key developmental processes (e.g. sexual differentiation), as well as increased susceptibility to chemical insult as adults. Exposure at maturity could also disrupt normal reproductive parameters (Arcand-Hoy and Ben son 1998).

Bisphenol A (BPA) is a commonly used name for 2,2-(4,4-dihydroxydiphenyl) propan. BPA is an industrially important compound used in many plastic applications, for example, plastic pipes, epoxy resins, and coating, and is discharged into the environment at manufacturing plants throughout the world (Staples et al. 1998). In 1993 the annual worldwide production of BPA reached 640000 tons, out of which an estimate $0.017 \%$ (109

Address for correspondence:

MVDr. Jana Drastichová, Ph.D.

University of Veterinary and Pharmaceutical Sciences

Palackého 1-3, 61242 Brno

Czech Republic
Phone: +420541562780

Fax: +420541562790

E-mail: janadrastich@email.cz

http://www.vfu.cz/acta-vet/actavet.htm 
tons) were released into the environment (Benjonathan and Steinmetz 1998; Staples et al. 1998). The environmental distribution has been estimated to be $32 \%$ in sediments, $43 \%$ in water, $24 \%$ in soil and $3.5 * 10^{-5 \%}$ in air (TemaNord, 1996). Besides mixing within the water column, BPA is subject to biodegradation, adsorption to suspended solids and sediments, and possibly photodegradation (Staples et al. 1998). Concentrations of bisphenol A in surface waters have been reported to be, in the most severe cases, as high as $17200 \mu \mathrm{g} \cdot \mathrm{l}^{-1}$ in leachates from hazardous waste landfill sites ( $\mathrm{Y}$ a $\mathrm{m}$ a m o t o et al. 2001), but usually concentrations have been around or below $1 \mu \mathrm{g} \cdot 1^{-1}$ (Belfoid et al. 2002, Fromme et al. 2002).

BPA has an estrogenic potency which has been demonstrated both in vitro and in vivo (Soto et al. 1995; Coldham et al. 1997; Kwak et al. 2001). Endocrine disrupters are effective at sublethal concentrations (Stahlschmidt-Allner et al. 1997). It is, therefore, not possible to detect effects of such compounds using existing standard tests with endpoints such as mortality. Great effort has been, therefore, put into this area to develop methods for testing endocrine disrupters containing new endpoints such as gonadal development and vitellogenin induction (Andersen et al. 2003).

One of the fish suggested as a test animal is the zebrafish, Danio rerio. In this species, males pass through a stage of juvenile hermafroditism. Approximately 10 days post hatch the differentiation of the gonads begins and all fish, irrespective of their definitive sex, develop ovaries. At approximately day 23 post hatch the ovaries of approximately half of the fish start to transform into testes. This process is completed at approximately 40 days post hatch. In the remaining fish, the development and maturation of ovaries continue (Takah as hi 1977). Due to the lability of sex differentiation in fish, exposure to endocrine disrupters during certain critical periods of early development can lead to sex reversal (Andersen et al. 2003).

In this study, zebrafish (D. rerio) was used to evaluate the estrogenic effects of bisphenol A and $17 ß$-estradiol presented in a diet on fish. Sex ratio and gonadal development of fry were investigated by histological methods. We tried to verify the hypothesis that bisphenol A and 17ß-estradiol presented not only in water but also in food can influence the fish organism.

\section{Materials and Methods}

The experiment on zebrafish was carried out in a semistatic test. Fish were divided into five groups: one control, three bisphenol treated and one estradiol treated group. Juvenile zebrafish (Danio rerio), 20 days post hatch (dph), were placed in two 15 litre glass aquaria (filled with 10 litre of water) for each test group in the number of 25 individuals in each aquarium, i.e. 50 individuals per group. The bath was changed three times a week. Basic physical and chemical indices of water used in the test were as follows: $\mathrm{pH} 7.67-7.98, \mathrm{ANC}_{4.5}$ (alkalinity) $3.5-3.8 \mathrm{mmol}^{-1} \mathrm{l}^{-1} \mathrm{COD}_{\mathrm{Mn}}$ 0.9 - $2.4 \mathrm{mg} \cdot \mathrm{l}^{-1}, \mathrm{BOD}_{5} 1.07-2.38 \mathrm{mg} \cdot \mathrm{l}^{-1}, \mathrm{NH}_{4}{ }^{+} 0 \mathrm{mg} \cdot \mathrm{l}^{-1}, \mathrm{NO}_{3}{ }^{-} 22.68-29.23 \mathrm{mg} \cdot \mathrm{l}^{-1}, \mathrm{NO}_{2}^{-} 0 \mathrm{mg} \cdot \mathrm{l}^{-1}$. During the test the water temperature varied between $23.2-24.9^{\circ} \mathrm{C}$. Water was continuously aerated. Oxygen saturation of water was above $60 \%$ (ranging from 79.1 to $90.5 \%$ ). Fish were kept on a photoperiod of $12: 12 \mathrm{~h}$.

Fish were fed three times a day with experimental diet. The test substances bisphenol A and 17ß-estradiol were dissolved in $96 \%$ ethanol. The ethanol solutions were mixed with brine shrimp eggs (Artemia salina, Sanders Brine Shrimp Company Inc.) decapsulated by the method of Adámk ová (1999). Resulting concentration of bisphenol A was $500 \mathrm{mg} \cdot \mathrm{kg}^{-1}, 1000 \mathrm{mg} \cdot \mathrm{kg}^{-1}$ and $2000 \mathrm{mg} \cdot \mathrm{kg}^{-1}$ of feed. Resulting concentration of estradiol was $20 \mathrm{mg} \cdot \mathrm{kg}^{-1} \mathrm{of}$ feed. The diet of control fish was treated with ethanol only. After thorough mixing, the ethanol was evaporated from the feed. Fish were fed approximately $2 \%$ of their body weight daily.

The experiment was terminated after 45 days at the fish age of $65 \mathrm{dph}, 220.85 \pm 43.78 \mathrm{mg}$ with mean body weight, and $21.4 \pm 1.74 \mathrm{~mm}$ mean body length. The sex was determined by histological method at 46 to 50 individuals from each group. Fish were fixed in $10 \%$ formalin, embedded in paraffin. The sex was confirmed by light microscopic evaluation of haematoxylin-eosin stained sections.

The Fisher's test was used to examine differences in sex ratio between the control group and exposure groups.

\section{Results}

The sex of fry in the zebrafish was identified by the morphology of gonads. Table 1 shows the sex ratio and the gonadal development of zebrafish. In the control group, the sex ratio of fry was 1:1 (female:male), i.e. $50 \%$ of females and $50 \%$ of males appeared. In the $17 ß-$ 
estradiol group, the sex ratio was 1:0, i.e. $100 \%$ of females appeared. The fish in this group showed an apparent alteration in sex ratio, which was highly statistically significant $(p<0.001)$ from the control group. In the bisphenol A groups, the sex ratio was 1.4:1 $(58 \%$ of females) in $500 \mathrm{mg} \cdot \mathrm{kg}^{-1}$ diet, 3.8:1 (79\% of females) in $1000 \mathrm{mg} \cdot \mathrm{kg}^{-1}$ diet and $11.5: 1(92 \%$ of females $)$ in $2000 \mathrm{mg} \cdot \mathrm{kg}^{-1}$ diet. There was no significant difference $(p=0.31)$ in the group fed with bisphenol A at the dose $500 \mathrm{mg} \cdot \mathrm{kg}^{-1}$ diet compared with the control. But there was a significant difference in the groups fed with bisphenol A at the dose $1000 \mathrm{mg} \cdot \mathrm{kg}^{-1} \operatorname{diet}(p=$ $0.01)$ and at the dose $2000 \mathrm{mg} \cdot \mathrm{kg}^{-1} \operatorname{diet}(p<0.01)$ compared with the control. No intersex individuals were found in any group tested.

In all groups, there were fish that could not be sex-determined. Occurrence of differentiated or undifferentiated gonadal tissue was not found in these animals, and they may have still been juvenile.

Table 1. Sex ratio of zebrafish (65 days post hatch) exposed to bisphenol A and 17ß-estradiol

\begin{tabular}{|lcrcccc|}
\hline Group & $\mathrm{n}$ & $\begin{array}{c}\text { females } \\
(\%)\end{array}$ & $\begin{array}{c}\text { males } \\
(\%)\end{array}$ & $\begin{array}{c}\text { sex ratio } \\
(\text { female: male })\end{array}$ & $\begin{array}{c}\text { sex determined } \\
(\%)\end{array}$ & probability \\
\hline Negative control & 50 & 50 & 50 & $1: 1$ & 84 & \\
Bisphenol A $\left(500 \mathrm{mg} \cdot \mathrm{kg}^{-1}\right)$ & 47 & 58 & 42 & $1.4: 1$ & 81 & \\
Bisphenol A $\left(1000 \mathrm{mg} \cdot \mathrm{kg}^{-1}\right)$ & 46 & 79 & 21 & $3.8: 1$ & 80 & $p=0.01$ \\
Bisphenol A $\left(2000 \mathrm{mg} \cdot \mathrm{kg}^{-1}\right)$ & 50 & 92 & 8 & $11.5: 1$ & 85 & $p<0.01$ \\
17ß-estradiol $\left(20 \mathrm{mg} \cdot \mathrm{kg}^{-1}\right)$ & 46 & 100 & 0 & $1: 0$ & 85 & $p<0.001$ \\
\hline
\end{tabular}

\section{Discussion}

One major purpose of the present investigation was to determine impact of bisphenol A and 17ß-estradiol on sex differentiation in juvenile zebrafish. Previous studies have shown that the most critical period for phenotypic sex determination occurs before and after hatching (Pandian and Sheela 1995). In the present study, zebrafish fed with a diet contaminated with bisphenol A at the dose of 1000 and $2000 \mathrm{mg} \cdot \mathrm{kg}^{-1}$ diet showed skewed sex ratio after 45 days of exposure to the experimental diet. The sex ratio of zebrafish fry was significantly different compared with the control group $(p=0.01$ and $p<0.01)$. Bisphenol A induced feminization of the fry at these two highest concentrations.

BPA is classified as slightly to moderately toxic to fish (Staples et al. 1998). However, current knowledge on bisphenol A toxicity for the early life stages of aquatic species, especially fish, is limited to very few studies. Lee et al. (2003) investigated the estrogenic effect of bisfenol A on the sex differentiation of Korean rockfish (Sebastes schlegeli). They fed the 51-day-old fry with food containing bisphenol A at the dose of 0.05, 0.5, 5, 50 and 100 $\mathrm{mg} \cdot \mathrm{kg}^{-1}$ for 29 days. After investigation of the sex ratio and gonadal development they observed no significant difference compared with the control fish. Their results are in accordance with our examination of zebrafish, because we did not observe estrogenic effect of bisphenol A at a concentration of $500 \mathrm{mg} \cdot \mathrm{kg}^{-1}$ on the sex differentiation compared with the control group. Shioda and Wakabayashi (2000) observed a significant decrease in the number of eggs and hatchings in medaka (Oryzias latipes) exposed to bisphenol A at a concentration of $10 \mu \mathrm{mol} \cdot \mathrm{l}^{-1}$. P a stv a et al. (2001) observed transient embryonic deformities in medaka (Oryzias latipes) embryos exposed to bisphenol A at a concentration of $200 \mu \mathrm{g} \cdot \mathrm{l}^{-1}$. Honkanen et al. (2004) observed morphological and histological changes in salmon yolk-sac fry exposed to bisphenol A at the concentration of 100 and $1000 \mu \mathrm{g} \cdot \mathrm{l}^{-1}$.

Bisphenol A also persists in sediments. Fromme et al. (2002) measured BPA at the concentrations from 0.01 to $0.19 \mathrm{mg} \cdot \mathrm{kg}^{-1}$ in sediments from riverbeds of 35 waterways in 
Germany. Concentrations of BPA up to $50 \mathrm{ng} \mathrm{g}^{-1}$ have been reported for sediments from the Masan Bay, Korea (Khim et al. 1999). Belfroid et al. (2002) measured BPA in the liver and muscle of bream (Abramis brama) and flounder (Platichthys flesus) at selected freshwater and marine locations in the Netherlands. An interesting point is that BPA was shown to be present even in flounder that lived at locations where no BPA was observed in the surface water. One explanation is that this bottom dwelling species feed primarily on benthic fauna, which might have accumulated BPA that had been absorbed to the sediment (Belfroid et al. 2002).

Presented results verified the hypothesis, that $17 ß$-estradiol and bisphenol A (in high concentrations) in food can influence a sex differentiation in juvenile zebrafish.

\section{Vliv bisfenolu A a 17ß-estradiolu na diferenciaci pohlaví u dánia pruhovaného (Danio rerio)}

Vliv bisfenolu A a 17ß-estradiolu na diferenciaci pohlaví byl zhodnocen u dánia pruhovaného, Danio rerio. 20-ti denní plůdek s nediferencovanými gonádami byl krmen dietou obsahující bisfenol A a 17ß-estradiol v koncentraci 500, 1000, $2000 \mathrm{mg} \cdot \mathrm{kg}^{-1}$ a $20 \mathrm{mg} \cdot \mathrm{kg}^{-1}$ po dobu 45 dnů. Poměr pohlaví a vývoj gonád byl určen na základě histologického vyšetření. V kontrolní skupině byl poměr pohlaví 1:1, tzn. $50 \%$ samic a $50 \%$ samců. Pohlaví u plůdku krmeného krmivem obsahujícím 17ß-estradiol v dávce $20 \mathrm{mg} \cdot \mathrm{kg}^{-1}$ bylo $100 \%$ samičí. Feminizace plůdku byla způsobena exogenním $17 ß$-estradiolem. Poměr pohlaví u plůdku krmeného krmivem obsahujícím bisfenol A v dávce 500, 1000, $2000 \mathrm{mg} \cdot \mathrm{kg}^{-1}$ bylo 1.4:1 $(p=0.31), 3.8: 1(p=0.01)$ a 11.5:1 $(p<0.01)$. Bisfenol A způsobil feminizaci plůdku ve dvou nejvyšších testovaných koncentracích.

\section{Acknowledgements}

This research was supported by the Ministry of Education, Youth and Sports of the Czech Republic (MSM project No. 6215712402).

\section{References}

ADÁMKOVÁ, I 1999: Method of decapsulation of stabile Artemia eggs and its use in aquaculture (in Czech). Research Institute of Fish Culture and Hydrobiology, Vodňany, Methods 58, 10 p.

ANDERSEN, L, HOLBECH, H, GESSBO, Å, NORRGREN, L, PETERSEN, GI 2003: Effects of exposure to 17 $\alpha$-ethinylestradiol during early development on sexual differentiation and induction of vitellogenin in zebrafish (Danio rerio). Comp Biochem Physiol C 134: 365-374

ARCAND-HOY, LD, BENSON, WH 1998: Fish reproduction: an ecologically relevant indicator of endocrine disruption. Environ Toxicol Chem 17: 49-57

BELFROID, A, VAN VELZEN, M, VAN DER HORST, B, VETHAAK, D 2002: Occurrence of bisphenol A in surface water and uptake in fish: evaluation of field measurements. Chemosphere 49: 97-103

BENJONATHAN, N, STEINMETZ, R 1998: Xenoestrogens - the emerging story of bisphenol A. Trends Endocrinol Metab 9: 124-128

BJERSELIUS, R, LUNDSTEDT-ENKEL, K, OLSÉN, H, MAYER, I, DIMBERG, K 2001: Male goldfish reproductive behaviour and physiology are severely affected by exogenous exposure to 17ß-estradiol. Aquat Toxicol 53: 139-152

COLDHAM, NG, MEHUL, D, SIVAPATHASUNDARAM, S, McDONNELL, DP, CONOR, C, SAUER, MJ 1997: Evaluation of a recombinant yeast cell estrogen screening assay. Environ Health Perspect 105: 734-742

FROMME, H, KÜCHLER, T, OTTO, T, PILZ, K, MÜLLER, J, WENZEL, A 2002: Occurrence of phthalates and bisphenol $\mathrm{A}$ and $\mathrm{F}$ in the environment. Water Res 36: 1429-1438

HONKANEN, JO, HOLOPAINEN, IJ, KUKKONEN, JVK 2004: Bisphenol A induces yolk-sac oedema and other adverse effects in landlocked salmon (Salmo salar m. sebago) yolk-sac fry. Chemosphere 55: 187-196

KHIM, JS, KANNAN, K, VILLENEUVE, DL, KOH, CH, GIESY, JP 1999: Characterisation and distribution of trace organic contaminants in sediment from Mansan Bay, Korea. 1. Instrumental analysis. Environ Sci Technol 33: 4199-4205

KWAK, HI, BAE, MO, LEE, MH, LEE, YS, LEE, BJ, KANG, KS, CHAC, CL, SUNG, HJ, SHIN, JS, KIM, JH, MAR, WC 2001: Effects of nonylphenol, bisphenol A, and their mixture on the viviparous swortail fish (Xiphophorus helleri). Environ Health Perspect 20: 787-795 
LEE, WK, LEE, KW, KWAK, EJ, YANG, SW, YANG, KS, PARK, JC, JOO, HS, LEE, WJ, LEE, WB 2003: Effects of environmental endocrine disrupters on the sex differentiation in Korean rockfish, Sebastes schlegeli. Water Sci Technol 47: 65-70

PANDIAN, TJ, SHEELA, SG 1995: Hormonal induction of sex reversal in fish. Aquaculture 138: 1-22

PASTVA, SD, VILLALOBOS, SA, KANNAN, K, GIESY, JP 2001: Morphological effects of Bisphenol A on the early life stages of medaka (Oryzias latipes). Chemosphere 45: 535-541

SHIODA, T, WAKABAYASHI, M 2000: Effect of certain chemicals on the reproduction of medaka (Oryzias latipes). Chemosphere 40: 239-243

SOTO, AM, SONNENSCHEIN, C, CHUNG, KL, FERNANDEZ, MF, OLEA, N, SERRANO, FO 1995: The Escreen assay as a tool to identify estrogens: an update on estrogenic environmental pollutants. Environ Health Perspect 103: 113-122

STAHLSCHMIDT-ALLNER, P, ALLNER, B, RÖMBKE, J, KNACKER, T 1997: Endocrine disrupters in the aquatic environment. Environ Sci Pollut Res 4: 155-162

STAPLES, CA, DORN, PB, KLECKA, GM, O'BLOCK, ST 1998: A review of the environmental fate, effects, and exposure of bisphenol A. Chemosphere 36: 2149-2173

TAKAHASHI, H 1977: Juvenile hermaphroditism in the zebrafish, Brachydanio rerio. Bull Fac Fish Hokkaido Univ 28: 57-65

TEMANORD, NORDIC COUNCIL OF MINISTERS, 1996: Chemicals with estrogen-like effects. Coppenhagen, pp. 35-51

TYLER, CR, JOBLING, S, SUMPTER, JP 1998: Endocrine disruption in wildlife: A critical review of the evidence. Crit Rev Toxicol 28: 319-361

YAMAMOTO, T, YASUHARA, A, SHIRAISI, H, NAKASUGI, O 2001: Bisphenol A in hazardous waste landfill leachates. Chemosphere 42: 415-418 